\title{
UPAYA REFORMASI BIROKRASI MELALUI AREA PERUBAHAN MENTAL APARATUR UNTUK MEMBERANTAS PRAKTIK PUNGUTAN LIAR YANG DILAKUKAN OLEH PNS
}

\author{
Vita Nurul Fathya \\ Politeknik Imigrasi \\ Email: vitafathya@gmail.com
}

\begin{abstract}
ABSTRAK
Permasalahan praktek pungli oleh PNS di Indonesia merupakan masalah klasik yang sudah seringkali dikeluhkan oleh masyarakat, namun belum ada penyelesaiannya, bahkan pungli semakin marak dilakukan. Tulisan ini membahas permasalahan pungli dari upaya pemerintah untuk memberantas pungli sebagai bagian dari program reformasi birokrasi area perubahan mental aparatur. Dibahas pula konsep tentang etika PNS yang dapat dijadikan masukan dalam memberantas pungli. Kesimpulannya bahwa untuk menghentikan PNS melakukan pungli, pemerintah dapat menerapkan standar etika yang efektif.
\end{abstract}

Kata kunci: PNS, reformasi, birokrasi, pungutan liar

\section{ABSTRACT}

Issues of illegal payment committed by civil servants in Indonesia are classical problems which have been complained many times by public, but so far there is no effective solution to end this practice. Even, this illegal payment is more frequently conducted. This article discusses the issue of illegal payment from the view on how the government makes an effort to eradicate this practice. This effort is a part of bureaucracy reform program namely the area to change the behavior and attitude of the civil servants. It is also discussed the concept of ethics in civil service that can be used as an input for government to remove the practice of illegal payment. The conclusion is that to make civil servants stop asking for illegal payment, government may implement effective ethics standards.

Keyword: civil servants, reform, bureaucracy, illegal payment

\section{PENDAHULUAN}

Perilaku negatif birokrat di Indonesia merupakan penghambat kinerja birokrasi di Indonesia. Dalam Road Map Reformasi Birokrasi 20152019 (Peraturan Menteri PAN dan RB, 2015) dijelaskan bahwa perilaku negatif aparatur sipil negara merupakan salah satu sumber permasalahan utama birokrasi. Dalam Road Map tersebut disinggung pula tentang citra buruk birokrasi akibat perilaku pegawai instansi pemerintah yang dipandang malas, lamban, tidak mau melayani, tidak inovatif, feodal, tidak peka terhadap perkembangan dunia luar, mempersulit masyarakat yang dilayani, dan lainnya. 
Vol.4, No.1, April 2018

Perilaku negatif aparatur yang banyak dikeluhkan masyarakat antara lain tindakan pungutan liar (pungli). Data dari Ombudsman Republik Indonesia (2017) yang melakukan pengawasan pelayanan publik bahwa pada Triwulan III 2017 (JuliSeptember 2017) terdapat 145 laporan dari masyarakat tentang perilaku aparatur yang meminta imbalan berupa uang/jasa. Aplikasi LAPOR, melalui situs www.lapor.go.id, yang dikembangkan oleh Kantor Staf Presiden Republik Indonesia juga menunjukkan data adanya laporan/pengaduan masyarakat tentang perilaku aparat (PNS) yang melakukan pungutan liar kepada masyarakat pengguna layanan publik. Sepanjang periode tahun 2016-2017, berdasarkan pemberitaan media online, menunjukkan cukup banyak aparatur sipil negara yang terkena operasi tangkap tangan akibat perilaku pungli antara lain yang dilakukan oleh PNS di Kementerian Perhubungan bulan Oktober 2016, PNS di Pemerintah Kabupaten Probolinggo bulan Oktober 2016, PNS di Disdukcapil Garut bulan Februari 2017, PNS di Disnakertrans Sidoarjo bulan Mei 2017, PNS di Cianjur bulan Agustus 2017, dan PNS di Pemerintah Kabupaten Bekasi bulan September 2017.

Penelitian tentang praktik pungutan liar sudah sering dilakukan baik dari pendekatan ilmu hukum maupun dari pendekatan ilmu sosial. Antara lain penelitian tentang efektivitas pengawasan pungutan liar di jembatan timbang (Wibawa, dkk, 2013), studi pungli yang dilakukan di terminal, stasiun kereta api, dan pelabuhan udara di Kota Bandung (Azhari, 2008), dan penerapan sanksi pidana penjara dan denda terhadap PNS yang melakukan tindak pidana korupsi pungutan liar (Harjanto, 2016). Penelitian tersebut menyoroti penyebab praktik pungli dan sanksi terhadap pelaku pungli. Namun, pembahasan tentang praktik pungli yang dikaitkan dengan kemajuan implementasi program reformasi birokrasi oleh pemerintah masih sedikit dilakukan. Adapun, tulisan yang mengkaitkan pungli dengan reformasi birokrasi antara lain dilakukan oleh Pusat Kajian Sistem dan Hukum Administrasi Negara dalam bentuk policy brief yang membahas tentang bagaimana mewujudkan birokrasi yang bebas dari pungutan liar sebagai hakikat agenda reformasi birokrasi (Pusat Kajian SANHAN, 2016).

Tulisan ini akan membahas upaya pemberantasan praktik pungutan liar dengan diterbitkannya Surat Edaran Menteri Pendayagunaan Aparatur Negara dan Reformasi Birokrasi Nomor 5 Tahun 2016 tentang Pemberantasan Praktik Pungutan Liar (Pungli) dalam 
Vol.4, No.1, April 2018

Pelaksanaan Tugas dan Fungsi Instansi Pemerintah. Selanjutnya ditinjau konsep tentang implementasi standar etika yang efektif yang dapat dijadikan bahan masukan dalam melakukan perubahan mental aparatur yang berujung pada pemberantasan pungli.

\section{PEMBAHASAN}

Reformasi Birokrasi sudah berjalan lebih dari lima tahun sejak dimulai pada tahun 2010 dengan diterbitkannya Peraturan Presiden Republik Indonesia Nomor 81 Tahun 2010 tentang Grand Design Reformasi Birokrasi 2010-2025. Dalam Road Map Reformasi Birokrasi 2015-2019 disebutkan bahwa seluruh kementerian dan lembaga termasuk pemerintah daerah di tingkat provinsi, kabupaten dan kota telah menjalankan program reformasi birokrasi (Peraturan Menteri PAN dan RB, 2015: i). Meski demikian diakui bahwa reformasi birokrasi pada periode 2010-2014 belum sepenuhnya sesuai dengan keinginan dan harapan masyarakat, yaitu masih ada penyimpangan yang dilakukan oleh aparatur.

Sebelum membahas bagaimana upaya pemerintah menghilangkan praktik pungli oleh PNS, akan dijelaskan secara umum tentang konsep reformasi birokrasi. Reformasi adalah cara yang dilakukan pemerintah untuk melakukan perubahan. Reformasi bertujuan untuk mengubah proses, prosedur, sikap dan perilaku. Perubahan adalah hasil reformasi. Perubahan diharapkan dapat menghasilkan lingkungan organisasi dan pengaturan kelembagaan yang baru (Huerto Mechor, 2008: 7-8). Untuk mengelola perubahan, organisasi memerlukan adanya adaptasi pola pikir, budaya dan sikap orang-orang terhadap lingkungan yang baru (Huerto Mechor, 2008: 14).

Reformasi birokrasi merupakan tantangan yang harus dipecahkan oleh pemerintah. Ini dikarenakan birokrasi adalah tulang punggung pemerintah, dimana ia mampu memperkuat atau merusak keseluruhan sistem tata kelola pemerintahan (Repucci, 2014: 207). Agar reformasi birokrasi dapat berjalan sesuai harapan, maka diperlukan dukungan dari pejabat di level tertinggi dari birokrasi atau champion of reform. Pejabat tinggi ini harus menunjukkan kepedulian terhadap keberhasilan perubahan dan bersedia memberi bantuan demi terlaksananya program reformasi. Akan lebih baik apabila pejabat tersebut merupakan pimpinan senior dari sebuah organisasi pemerintah dan memiliki jaringan yang luas dengan berbagai pihak. Sebagai pejabat senior, maka ia mampu meredam penolakan dari para pegawai dari jajaran di bawahnya terhadap upaya perubahan yang sedang dijalankan (Repucci, 2014: 211). 
Dalam melaksanakan reformasi birokrasi, perlu ada dua aspek utama yang diperhatikan yaitu aspek perubahan dan aspek orang. Perubahan tidak dapat dipaksakan, tetapi dilakukan dengan cara adaptasi. Pimpinan organisasi perlu membujuk orang-orang agar mau berubah (Huerto Mechor, 2008: 19). Pimpinan organisasi juga harus mampu menginspirasi para pegawai negeri sipil agar memiliki komitmen untuk berubah. Dalam melakukan perubahan juga diperlukan pendekatan partisipatif dengan melibatkan semua orang dalam organisasi (Huerto Mechor, 2008: 29).

Dalam melakukan perubahan, ada beberapa hal yang perlu dipertimbangkan. Pertama, perubahan itu harus sederhana dan mudah dipahami (Huerto Mechor, 2008: 3637). Kedua, perubahan harus konsisten dengan melakukan langkah-langkah perubahan sesuai tahapan. Ketiga, perubahan harus berdasarkan data dan informasi yang benar. Keempat, perubahan harus dapat dicapai sesuai dengan kondisi yang ada dan jangka waktu yang masuk akal. Kelima, perubahan harus mampu mengidentifikasi masalah yang muncul sebagai dampak dari perubahan tersebut dan melakukan tindakan yang tepat untuk mengatasi resiko tersebut. Keenam, perubahan harus berorientasi ke masa depan karena dampak perubahan jarang dapat dirasakan dalam waktu singkat.

Fokus keberlanjutan reformasi birokrasi periode 2015-2019 yang tercantum dalam road map adalah melakukan penguatan melalui langkah-langkah memelihara dan memperkuat area perubahan, melanjutkan upaya perubahan positif, mencari solusi permasalahan birokrasi dan memperluas cakupan implementasi perubahan dengan mengadaptasi perkembangan terbaru. Dari pencapaian reformasi birokrasi periode 2010-2014, menunjukkan bahwa pelayanan publik belum memiliki kualitas sesuai harapan. Salah satu masalah yang menyebabkan rendahnya kualitas pelayanan tersebut adalah praktik pungli. Adanya biayabiaya tambahan di luar biaya resmi menyebabkan tingginya biaya untuk memperoleh layanan tersebut.

Maraknya praktik pungli yang dilakukan PNS dan sering dikeluhkan oleh masyarakat mendorong pemerintah untuk melakukan berbagai upaya untuk memberantas pungli tersebut. Upaya pemerintah misalnya membentuk Satuan Tugas Sapu Bersih Pungutan Liar (Satgas Saber Pungli) berdasarkan Peraturan Presiden Republik Indonesia Nomor 87 Tahun 2016. Selain membentuk Satgas Saber Pungli, ada langkah-langkah lain untuk mendukung perubahan di bidang aparatur negara, seperti antara lain: 
Vol.4, No.1, April 2018

- Pemerintah melakukan penataan peraturan dan kebijakan di bidang aparatur negara sebagaimana disebutkan dalam road map reformasi birokrasi 2015-2019.

- Penguatan reward dan punishment secara fair menjadi isu strategis dan agenda prioritas reformasi birokrasi 2015-2019 dan dilakukan oleh seluruh Kementerian/Lembaga/Pemerintah Daerah.

- Penguatan budaya integritas, budaya kerja dan budaya melayani menjadi isu strategis dan agenda prioritas reformasi birokrasi 20152019 dan dilakukan oleh seluruh kementerian/lembaga/pemerintah daerah.

- Mental aparatur menjadi salah satu area perubahan dalam road map reformasi birokrasi 2015-2019 dengan maksud agar terjadi perubahan mental dan perilaku aparatur ke arah yang positif demi terciptanya budaya kerja kondusif untuk menciptakan birokrasi yang bersih dan akuntabel, efektif dan efisien, serta mampu memberikan pelayanan yang berkualitas.

- Komisi Pemberantasan Korupsi menerbitkan Pedoman Pengendalian Gratifikasi pada tahun 2015 yang memuat batasanbatasan bagi pegawai negeri sipil untuk menerima pemberian dari masyarakat yang dilayani (Komisi Pemberantasan Korupsi, 2015).

Salah satu fokus area reformasi birokrasi pada periode 2015-2019 adalah melakukan perubahan mental aparatur. Perubahan mental aparatur dilakukan karena merupakan inti dari perubahan melalui program reformasi birokrasi. Namun dalam implementasinya, tidak hanya melakukan perubahan mental aparatur saja, tetapi juga perlu diiringi dengan perubahan-perubahan sistem yang melingkupi aparatur tersebut (Peraturan Menteri PAN dan RB, 2015: 32). Untuk lebih jelasnya dapat dilihat dari gambar di bawah ini. 
Vol.4, No.1, April 2018

Gambar 1. Siklus Perubahan Sistem Aparatur

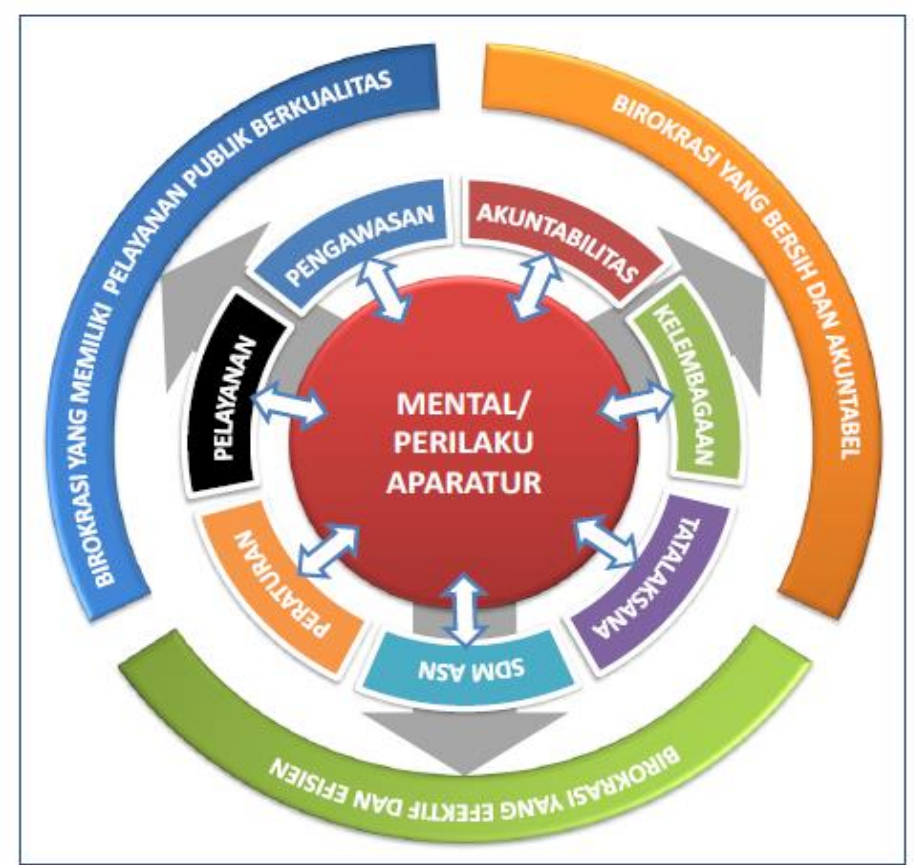

Sumber: Peraturan Menteri PAN dan RB, 2015

Hasil akhir yang diharapkan dari road map reformasi birokrasi 2015-2019 pada area perubahan mental aparatur adalah:

- Meningkatnya

penerapan/internalisasi asas, prinsip, nilai dasar, kode etik, dan kode perilaku, termasuk penguatan budaya kinerja dan budaya pelayanan

- Meningkatnya penerapan budaya kerja positif di setiap instansi pemerintah

- Meningkatnya integritas aparatur

- Meningkatnya profesionalisme aparatur
- Meningkatnya citra positif aparatur sebagai pelayan masyarakat

- Meningkatnya kepuasan masyarakat

Berikut adalah upaya Kementerian PAN dan RB dalam melakukan perubahan mental aparatur yang bertujuan untuk mengurangi dan memberantas praktik pungli yang dilakukan oleh pegawai negeri sipil. Upaya ini diwujudkan dalam bentuk Surat Edaran yang berisi sejumlah langkah untuk menjadi perhatian pimpinan

kementerian/lembaga/pemerintah daerah dalam menghilangkan pungli 
Vol.4, No.1, April 2018

dan sekaligus sebagai bagian dari upaya konkrit reformasi birokrasi.

\section{Surat Edaran Menteri Pendayagunaan Aparatur Negara dan Reformasi Birokrasi Nomor 5 Tahun 2016 tentang Pemberantasan Praktik Pungutan Liar (Pungli) dalam Pelaksanaan Tugas dan Fungsi Instansi Pemerintah}

Surat edaran ini merupakan tindak lanjut instruksi Presiden Republik Indonesia tentang pemberantasan pungli, yaitu memperingatkan seluruh kementerian dan instansi agar menghentikan segala bentuk pungutan liar, terutama dalam bidang yang menyangkut pelayanan kepada masyarakat (Kementerian Dalam Negeri, 2016).

Surat edaran Menteri PAN dan RB memerintahkan kepada seluruh pimpinan

kementerian/lembaga/pemerintah daerah untuk melakukan sejumlah langkah pemberantasan pungli (Kementerian PAN dan RB, 2016). Langkah-langkah yang dimaksud dalam surat edaran tersebut adalah agar seluruh instansi pemerintah:

a. Mengidentifikasi area yang berpotensi terjadinya pungutan liar dan mengambil langkah-langkah yang efektif untuk memberantas praktik-praktik pungutan liar; b. Menindak tegas Aparatur Sipil Negara (ASN) yang terlibat sebagai pelaku pungutan liar;

c. Melakukan investigasi lebih mendalam untuk menjaring keterlibatan oknum-oknum lain;

d. Memberlakukan/mengembangkan sistem pelayanan berbasis teknologi informasi untuk mengurangi pertemuan langsung antara pemberi dan penerima layanan;

e. Memberi akses yang seluasluasnya kepada masyarakat terhadap standar pelayanan dan persyaratan pelayanan secara transparan;

f. Meningkatkan sistem pengawasan internal untuk mencegah terjadinya praktik pungutan liar;

g. Melakukan upaya untuk meningkatkan integritas Aparatur Sipil Negara di lingkungannya masing-masing;

h. Membuka akses yang murah dan mudah bagi masyarakat untuk menyampaikan keluhan dan pengaduan, serta mendorong masyarakat untuk tidak segansegan melakukan pengaduan;

i. Melakukan respon secara cepat terhadap pengaduan-pengaduan yang disampaikan oleh masyarakat;

j. Menerapkan sistem pengaduan internal (whistle blower system) 
Vol.4, No.1, April 2018

untuk membuka dan atau mencegah praktik pungutan liar;

k. Menugaskan Aparat Pengawasan Intern Pemerintah (APIP) untuk mendorong dan memantau langkah-langkah instansi pemerintah dalam mencegah dan mendeteksi terjadinya pungutan liar;

1. Mengumumkan hasil-hasil penindakan secara rutin kepada seluruh ASN di lingkungan instansi pemerintah masingmasing, sebagai pelajaran untuk memberikan efek jera bagi ASN lainnya agar tidak melakukan perbuatan serupa.

Upaya pemerintah melalui Surat Edaran Menteri PAN dan RB untuk melakukan perubahan mental aparatur yang dibagi ke dalam sebelas langkah di atas patut diapresiasi dengan beberapa alasan. Pertama, dengan teridentifikasinya titik-titik pelayanan yang rawan pungli maka akan lebih mudah bagi instansi pemerintah untuk memantau pegawai negeri sipil yang bertugas di pelayanan yang bersentuhan langsung dengan masyarakat. Dengan demikian, apabila ada indikasi pegawai melakukan pelanggaran dan penyimpangan, dapat dengan mudah diantisipasi dan dikendalikan untuk segera dihentikan praktik pelanggaran dan penyimpangan tersebut. Ini semakin diperkuat dengan instruksi penjatuhan tindakan tegas bagi pelaku pungli agar terdapat efek jera. Tindakan tegas bagi pelaku pungli diharapkan juga dapat mencegah pegawai lain yang berniat untuk melakukan tindakan serupa karena mengetahui sanksi yang akan diperoleh.

Kedua, penggunaan aplikasi elektronik dalam pelayanan mendukung upaya pencegahan praktik pungli karena semakin kecil frekuensi pertemuan antara petugas pelayanan dengan masyarakat yang dilayani, maka diharapkan akan semakin memperkecil peluang terjadinya pungli. Ini semakin diperkuat dengan pemberian akses informasi kepada masyarakat tentang prosedur pelayanan sehingga masyarakat paham bagaimana memperoleh pelayanan tanpa harus khawatir akan dipersulit oleh petugas yang berdalih membantu namun dengan tujuan melakukan pungli.

Ketiga, sistem pengawasan internal kepada pegawai yang diperkuat dengan mengoptimalkan whistle blower system dan dilibatkannya peran APIP dalam memetakan langkah yang dapat diambil oleh instansi pemerintah dalam mencegah dan mendeteksi peluang terjadinya praktik pungli, diharapkan dapat semakin memperkecil peluang praktik pungli. Ditambah dengan upaya 
menyebarluaskan hasil penindakan atas pelanggaran disiplin pegawai yang melakukan pungutan liar sehingga dapat dijadikan pelajaran bagi pegawai lain yang berniat melakukan pungli dan menjadi efek jera bagi pelaku pungli itu sendiri.

\section{Keempat, peningkatan} pemahaman seluruh pegawai negeri sipil melalui pelatihan tentang implementasi nilai-nilai integritas dalam pelaksanaan tugas dan fungsi masing-masing diharapkan dapat membentengi pegawai dari niat dan keinginan untuk menambah penghasilan dari praktik pungli. Terlebih lagi dengan dibukanya saluran penerimaan pengaduan dan keluhan masyarakat yang dapat diakses dengan mudah dan murah serta direspon dengan cepat dan tepat, diharapkan mendorong masyarakat untuk tidak segan-segan menyampaikan pengaduan apabila menerima layanan yang kurang baik.

Surat Edaran Menteri PAN dan RB merupakan langkah awal untuk mendorong perubahan mental aparatur ke arah positif dalam jangka panjang. Namun demikian, surat edaran tersebut belum secara efektif dapat membendung praktik pungli oleh PNS. Setelah surat edaran tersebut diterbitkan, sebagaimana dijelaskan dalam bagian pendahuluan, masih ada PNS yang terjaring pelanggaran hukum karena melakukan praktek pungli. Untuk itu, pemerintah dalam hal ini kementerian/lembaga/pemerintah daerah perlu memunculkan berbagai inovasi dan praktek terbaik untuk mencegah pungli di instansi masingmasing.

\section{Konsep tentang Implementasi Standar Etika yang Efektif}

Salah satu langkah untuk memberantas pungli dalam Surat Edaran Menteri PAN dan RB adalah meningkatkan integritas PNS. Howard Whitton (2001) mengemukakan sejumlah langkah untuk membentuk integritas yang tinggi di kalangan pegawai dalam birokrasi. Masalah integritas PNS menjadi hal yang penting karena tuntutan masyarakat yang menginginkan agar perilaku koruptif dalam birokrasi dapat diberantas (Whitton, 2001: 1).

Untuk meningkatkan integritas, ada tiga hal yang perlu diperhatikan (Whitton, 2001). Pertama, mengidentifikasi ancaman terhadap integritas dalam birokrasi. Jika ancaman dapat diidentifikasi, maka langkah-langkah antisipasi dapat dijalankan. Kedua, memperkuat kompetensi etika PNS dan mekanisme pendukung etika profesional. Perlu ada cara-cara baru yang dilakukan pemerintah agar budaya etika birokrasi yang bersih dan melayani dapat diterapkan, terutama menyangkut 
disiplin PNS, tanggung jawab melaksanakan tugas dan mematuhi aturan yang berlaku.

Secara strategis, Whitton (2001) menerangkan bahwa selain ketiga hal diatas, perlu juga mempertimbangkan beberapa hal, yaitu:

- aturan bagi PNS untuk menjelaskan alasan keputusan dan tindakan yang dilakukannya, misalnya aturan tentang keterbukaan informasi publik.

- pendekatan manajemen yang mampu mencegah PNS dari perilaku koruptif dan pelanggaran etika.

- aturan untuk melindungi PNS yang memberikan informasi tentang penyimpangan dalam birokrasi (whistleblower).

- audit terhadap pelanggaran etika terutama berkaitan dengan pengelolaan keuangan, pengadaan barang dan jasa, rekrutmen dan promosi jabatan, serta disiplin pegawai.

- strategi manajemen sumber daya manusia untuk memantau tingkat kinerja etika yang rendah.

- penyelenggaraan pendidikan dan pelatihan untuk meningkatkan kompetensi pegawai dalam menerapkan nilai-nilai integritas.

- prosedur penanganan pengaduan dan keluhan yang efektif baik dari kalangan internal pegawai maupun dari eksternal masyarakat.

Standar etika yang dirujuk dalam tulisan ini dibagi ke dalam delapan pembahasan sebagai berikut.

1) Kode Etik dan Kode Perilaku Standar etika dalam birokrasi biasanya dituangkan dalam bentuk kode etik dan kode perilaku. Dalam Undang-Undang Nomor 5 Tahun 2014 tentang Aparatur Sipil Negara, juga dicantumkan bahwa PNS harus mematuhi kode etik dan kode perilaku. Pasal 5 Undang-Undang tersebut mencantumkan bahwa kode etik dan kode perilaku berisi pengaturan perilaku dengan salah satu harapannya bahwa PNS melaksanakan tugasnya dengan jujur, bertanggung jawab dan berintegritas tinggi.

Kode etik dapat diartikan sebagai nilai-nilai inti untuk membentuk perilaku PNS yang profesional. Kode etik biasanya memuat nilai-nilai integritas, akuntabilitas, tanggung jawab, dapat dipercaya dan lain sebagainya. Namun hanya sedikit perhatian dari pimpinan organisasi bagaimana menerapkan prinsip-prinsip tersebut dalam praktek pelaksanaan tugas sehari-hari (Whitton, 2001: 3). Selanjutnya, Whitton juga menjelaskan tentang pengertian kode perilaku yaitu sejumlah standar bagaimana perilaku yang diharapkan oleh organisasi dalam 
pelaksanaan tugas sehari-hari yang sesuai dengan norma dan nilai, serta ketentuan yang berlaku.

Terkait dengan peningkatan integritas PNS, pemerintah telah menerbitkan Peraturan Pemerintah Nomor 42 Tahun 2004 tentang Pembinaan Jiwa Korps dan Kode Etik Pegawai Negeri Sipil. Bahkan beberapa instansi pemerintah juga sudah memiliki aturan tentang kode etik pegawai di lingkungannya masing-masing. Menurut Whitton, setiap instansi pemerintah perlu menetapkan kode etik masing-masing karena situasi yang dihadapi oleh PNS di setiap instansi tidak sama. Demikian pula dengan masalah yang dihadapi oleh setiap instansi juga berbeda-beda.

Namun, keberadaan aturan kode etik ini belum memotivasi PNS untuk menjauhi tindak pelanggaran seperti pungli. Ini seperti yang disampaikan Whitton (2001) bahwa keberadaan kode etik tersebut hanya memiliki pengaruh yang kecil terhadap perilaku PNS. Terlebih lagi kebanyakan kode etik tersebut hanya memuat prinsip-prinsip umum yang kurang jelas dan kurang spesifik. Namun, hal yang paling penting menurut Whitton adalah bahwa kode etik tersebut dikaitkan dengan komitmen dari pimpinan tertinggi dan praktek manajemen birokrasi sesuai prosedur agar penerapannya dapat sesuai dengan sasaran yaitu meningkatnya disiplin dan kepatuhan pegawai terhadap aturan.

Masalah utama dalam menjalankan kode etik oleh para PNS dalam birokrasi adalah PNS tidak memiliki kompetensi teknis untuk memahami apa saja masalah etika dalam pekerjaan mereka. Mereka juga tidak mengetahui apa saja harapan organisasi terhadap mereka mengenai penerapan standar etika. Yang lebih buruk lagi adalah mereka tidak memiliki kepentingan pribadi atau kepentingan profesional untuk menerapkan nilai-nilai integritas (Whitton, 2001: 3).

Whitton (2001: 4-5) menjelaskan bahwa umumnya kode etik pegawai negeri sipil mengandung prinsip-prinsip berikut:

a. melayani kepentingan publik;

PNS harus memelihara dan memperkuat kepercayaan publik dan keyakinan masyarakat terhadap pemerintah. Dalam menjalankan hal tersebut, PNS harus memiliki kompetensi profesional, efisien, efektif, mematuhi peraturan yang berlaku serta selalu mengutamakan kepentingan umum.

b. transparansi;

PNS harus menggunakan alokasi sumber daya untuk kepentingan umum, sesuai dengan kebijakan yang ditetapkan pemerintah. PNS harus bertanggungjawab atas setiap 
keputusan yang diambil dan setiap tindakan yang dilakukan kepada masyarakat.

c. integritas;

PNS harus menjalankan tugasnya dengan mengutamakan kepentingan masyarakat di atas kepentingan pribadi. Menggunakan wewenang sebagai PNS untuk melakukan tindakan demi kepentingan pribadi sehingga menimbulkan ketidakpercayaan masyarakat terhadap pemerintah merupakan suatu pelanggaran serius atas tugas yang dimilikinya.

d. legitimasi;

PNS harus menjalankan tugasnya sesuai dengan peraturan yang berlaku. Dalam menjalankan tugas sebagai seorang PNS harus sesuai dengan amanah peraturan yang diembankan kepadanya, adil dan tidak memihak satu kelompok tertentu.

e. adil;

PNS harus bertindak dan memutuskan sesuai dengan adil, tanpa prasangka terhadap pihak yang dilayani, mempertimbangkan segala aspek terkait dan tidak merugikan kepentingan masyarakat.

f. tanggap

PNS harus memenuhi dan melayani kepentingan negara, kepentingan pemerintah, kepentingan, kepentingan PNS lain, dan kepentingan seluruh warga negara dengan cara yang tepat waktu, dengan rasa peduli, dengan menghormati dan dengan sopan.

g. efisien dan efektif;

PNS harus memberikan nilai terbaik untuk barang publik yang digunakan oleh birokrasi dan tidak menghambur-hamburkan uang negara.

\section{2) Standar Pelayanan}

Untuk mereformasi birokrasi area perubahan mental aparatur, umumnya menetapkan standar pelayanan yang mempertimbangkan aspek pelayanan dan akuntabilitas untuk melengkapi etika dan perilaku PNS. Whitton memberikan penjelasan tentang aspek-aspek yang perlu dipertimbangkan menetapkan standar pelayanan sebagai berikut:

- pelayanan: masyarakat berhak untuk mendapatkan pelayanan dari berbagai bidang. PNS diharapkan untuk memberikan pelayanan dengan sebaik-baiknya kepada masyarakat. Setiap hambatan administrasi dalam birokrasi yang mempengaruhi penyelenggaraan pelayanan yang efektif harus diidentifikasi dan dihilangkan.

- akuntabilitas: keputusan yang dibuat oleh PNS harus transparan dan terbuka. Setiap keputusan 
Vol.4, No.1, April 2018

resmi yang dibuat harus disertai alasan yang melatarbelakanginya.

- pengaduan/keluhan: PNS

diharapkan memberikan

mekanisme yang efektif di mana masyarakat dapat menyalurkan pengaduan atau keluhan atas kinerja birokrasi dan mendapatkan tanggapan dan penyelesaian terhadap pengaduan atau keluhan tersebut. Setiap proses pengaduan atau keluhan harus dipantau oleh tiap instansi untuk menjamin bahwa sistem dievaluasi dan kinerja ditingkatkan.

Menurut Whitton, standar pelayanan memerlukan sejumlah aturan baku untuk menunjang pelayanan pemerintah. Standar pelayanan dapat juga digunakan untuk menegakkan standar perilaku etika misalnya melarang menerima suap, mendorong akuntabilitas kinerja misalnya melakukan perbaikan berdasarkan pengaduan atau keluhan, dan keadilan prosedur misalnya membuat keputusan sesuai aturan yang berlaku. Dengan adanya standar pelayanan maka akan memberi akses yang lebih besar kepada publik untuk memperoleh kualitas pelayanan yang lebih baik. Selain itu, standar pelayanan juga membuat pemerintah dan PNS menjadi lebih transparan dan akuntabel (Whitton, 2001: 6). Selanjutnya Whitton menambahkan bahwa adanya standar pelayanan akan lebih mudah mendeteksi korupsi dan pelanggaran lain yang dilakukan PNS dan akan mudah pula dikoreksi. Standar pelayanan akan mempermudah mengidentifikasi kinerja PNS yang rendah, hambatan administratif, maladministrasi, dan penyalahgunaan wewenang dalam pengambilan keputusan administratif.

\section{3) Maladministrasi}

Upaya perubahan mental aparatur dalam birokrasi khususnya terkait dengan pemberantasan praktek pungli perlu juga melihat konsep maladministrasi. Menurut Whitton, maladministrasi merupakan pembuatan keputusan dengan cara yang tidak sesuai hukum, sewenang-wenang, tanpa pertimbangan yang matang, tidak sesuai prosedur, atau dibuat tanpa memperhitungkan masalah kepatutan, atau dilakukan dengan caracara koruptif. Maladministrasi jika dikaitkan dengan perilaku pungli maka merupakan bentuk penyalahgunaan wewenang untuk kepentingan pribadi. Apapun alasannya, perbuatan maladministrasi adalah perbuatan yang melanggar etika.

\section{4) Keterbukaan Informasi Publik}

Pemerintah perlu memberikan hak kepada masyarakat untuk memperoleh informasi tentang berbagai keputusan dan tindakan yang 
Vol.4, No.1, April 2018

diambil. Menurut Whitton, keterbukaan informasi kepada publik bukan berarti bahwa semua informasi pemerintah harus diberikan kepada masyarakat. Keterbukaan informasi publik, lanjut Whitton, harus memperhatikan kepentingan nasional, ekonomi, penyelidikan masalah pidana, keamanan nasional, dan seberapa penting informasi tersebut diberikan kepada publik (Whitton, 2001: 7).

\section{5) Perlindungan Whistleblower}

terhadap

Upaya untuk memberantas perilaku pungli perlu memperhatikan masalah perlindungan terhadap PNS atau orang dalam yang melaporkan adanya tindakan pelanggaran tersebut (whistleblower). Menurut Whitton, upaya memberikan perlindungan kepada whistleblower dapat berupa dorongan kepada PNS untuk menjadi pelapor adanya pungli dengan jaminan perlindungan bahwa laporan mereka tidak diketahui oleh rekan PNS lainnya dan mereka akan dilindungi dari tindakan balasan dari PNS yang mereka laporkan. Perlindungan terhadap pelapor juga harus diikuti dengan adanya hukuman yang berat bagi PNS yang dilaporkan melakukan pungli. Namun tetap perlu diperhatikan bahwa laporan dari whistleblower tersebut adalah laporan yang benar dan sesuai dengan fakta di lapangan, sehingga tidak membuat laporan palsu.

\section{6) Uji Integritas}

Upaya untuk mengubah mental aparatur dapat dilakukan dengan menggunakan uji integritas. Whitton (2001) menjelaskan bahwa uji integritas adalah salah satu cara untuk mendorong kepatuhan PNS terhadap kode etik dan kode perilaku. Uji integritas biasanya digunakan untuk mendeteksi PNS yang rentan menerima suap atau pungli akibat wewenang yang dimiliki jabatannya, yaitu untuk melakukan atau tidak melakukan suatu tindakan yang melanggar ketentuan. Uji integritas harus menggambarkan situasi nyata yang dihadapi PNS dalam melakukan pekerjaannya sehari-hari. Hasil uji integritas harus dievaluasi secara independen sehingga tidak merugikan PNS yang diuji.

\section{7) Tanggung \\ Masyarakat}

Jawab

Whitton (2001) menjelaskan bahwa masyarakat dalam berhubungan dengan PNS harus menerapkan perilaku jujur, taat hukum, dan menghindari perilaku koruptif. Masyarakat perlu didorong untuk menjauhi perilaku yang dapat mempengaruhi PNS untuk melakukan tindakan pelanggaran seperti pungli. Masyarakat juga diharapkan untuk 
Vol.4, No.1, April 2018

melaporkan PNS yang melakukan pelanggaran. Jika ada warga masyarakat yang berusaha mempengaruhi PNS untuk melakukan perilaku koruptif, maka pemerintah dapat memberlakukan sanksi administratif yaitu dengan tidak memberikan pelayanan kepada warga tersebut selama periode tertentu. Sanksi ini harus dievaluasi secara independen agar tidak merugikan warga masyarakat tersebut. Diharapkan peran masyarakat ini dapat mengurangi praktek pungli oleh PNS.

\section{8) Reformasi Manajemen Sumber Daya Manusia \\ Manajemen sumber daya} manusia memiliki peran penting dalam memantau penerapan kode etik dan kode perilaku PNS (Whitton, 2001: 11). Birokrasi yang tidak mampu mengimplementasikan kode etik bagi PNS maka tidak akan mampu mencegah perilaku pungli dan tidak akan mampu memberikan pelayanan yang berkualitas kepada masyarakat.

3. Perbandingan antara Surat Edaran Menteri PAN dan RB dengan Konsep Implementasi Standar Etika dalam Birokrasi

$$
\text { Mengacu pada konsep }
$$

implementasi standar etika birokrasi yang disampaikan Whitton (2001), maka dapat dibandingkan dengan Surat Edaran Menteri PAN dan RB terkait pemberantasan pungli sebagai berikut.

Tabel 1.

Perbandingan antara Konsep Implementasi Standar Etika Birokrasi dengan Surat Edaran Menteri PAN dan RB untuk memberantas Pungli

\begin{tabular}{|c|c|}
\hline $\begin{array}{c}\text { Konsep Implementasi } \\
\text { Standar Etika oleh Whitton }\end{array}$ & $\begin{array}{c}\text { Surat Edaran } \\
\text { Menteri PAN dan RB }\end{array}$ \\
\hline $\begin{array}{l}\text { - Mengidentifikasi ancaman terhadap } \\
\text { integritas dalam birokrasi. Jika } \\
\text { ancaman dapat diidentifikasi, maka } \\
\text { langkah-langkah antisipasi dapat } \\
\text { dijalankan }\end{array}$ & $\begin{array}{l}\text { - Mengidentifikasi area yang } \\
\text { berpotensi terjadinya pungutan liar } \\
\text { dan mengambil langkah-langkah } \\
\text { yang efektif untuk memberantas } \\
\text { praktik-praktik pungutan liar }\end{array}$ \\
\hline $\begin{array}{l}\text { - Adanya hukuman yang berat bagi } \\
\text { PNS yang dilaporkan melakukan } \\
\text { pungli }\end{array}$ & $\begin{array}{l}\text { - Menindak tegas Aparatur Sipil } \\
\text { Negara (ASN) yang terlibat sebagai } \\
\text { pelaku pungutan liar }\end{array}$ \\
\hline - Tidak dibahas & $\begin{array}{l}\text { - Melakukan investigasi lebih } \\
\text { mendalam untuk menjaring } \\
\text { keterlibatan oknum-oknum lain }\end{array}$ \\
\hline
\end{tabular}


Vol.4, No.1, April 2018

- Tidak dibahas
- Memberlakukan/mengembangkan sistem pelayanan berbasis teknologi informasi untuk mengurangi pertemuan langsung antara pemberi dan penerima layanan

- Penerapan standar pelayanan untuk menegakkan standar perilaku etika (melarang menerima suap), mendorong akuntabilitas kinerja (melakukan perbaikan berdasarkan pengaduan atau keluhan), dan keadilan prosedur (membuat keputusan sesuai aturan yang berlaku)

- Tidak dibahas

- Meningkatkan sistem pengawasan internal untuk mencegah terjadinya praktik pungutan liar
- Memberi akses yang seluas-luasnya kepada masyarakat terhadap standar pelayanan dan persyaratan pelayanan secara transparan
- Penyelenggaraan pendidikan dan pelatihan untuk meningkatkan kompetensi pegawai dalam menerapkan nilai-nilai integritas

- Prosedur penanganan pengaduan dan keluhan yang efektif baik dari kalangan internal pegawai maupun dari eksternal masyarakat

- Melakukan upaya untuk meningkatkan integritas Aparatur Sipil Negara di lingkungannya masing-masing

- Membuka akses yang murah dan mudah bagi masyarakat untuk menyampaikan keluhan dan pengaduan, serta mendorong masyarakat untuk tidak segan-segan melakukan pengaduan
- Prosedur penanganan pengaduan dan keluhan yang efektif baik dari kalangan internal pegawai maupun dari eksternal masyarakat

- Aturan untuk melindungi PNS yang memberikan informasi tentang penyimpangan dalam birokrasi (whistleblower)

- Tidak dibahas

- Melakukan respon secara cepat terhadap pengaduan-pengaduan yang disampaikan oleh masyarakat

- Menerapkan sistem pengaduan internal (whistle blower system) untuk membuka dan atau mencegah praktik pungutan liar

- Menugaskan Aparat Pengawasan Intern Pemerintah (APIP) untuk mendorong dan memantau langkahlangkah instansi pemerintah dalam mencegah dan mendeteksi terjadinya pungutan liar

- Hak kepada masyarakat untuk memperoleh informasi tentang
- Mengumumkan hasil-hasil penindakan secara rutin kepada 
Vol.4, No.1, April 2018

berbagai keputusan dan tindakan

yang diambil seluruh ASN di lingkungan instansi

pemerintah masing-masing, sebagai

pelajaran untuk memberikan efek jera

bagi ASN lainnya agar tidak

melakukan perbuatan serupa

- Memperkuat kompetensi etika PNS

- Tidak ada

dan mekanisme pendukung etika

profesional. Perlu ada cara-cara baru

yang dilakukan pemerintah agar

budaya etika birokrasi yang bersih

dan melayani dapat diterapkan, terutama menyangkut disiplin PNS, tanggung jawab melaksanakan tugas dan mematuhi aturan yang berlaku

- Pendekatan manajemen yang mampu mencegah PNS dari perilaku koruptif dan pelanggaran etika. Misalnya, strategi manajemen sumber daya manusia untuk memantau tingkat kinerja etika yang rendah

- Penegakan Kode Etik dan Kode - Tidak ada Perilaku untuk meningkatkan disiplin dan kepatuhan pegawai

- Upaya pencegahan maladministrasi oleh PNS

- Pelaksanaan uji integritas

- Peningkatan pemahaman kepada masyarakat untuk tidak mempengaruhi PNS melakukan pungli

Menurut tabel di atas, ada beberapa konsep standar etika yang sudah dimuat dalam Surat Edaran Menteri PAN dan RB terkait pungli. Meski demikian, ada sejumlah langkah yang tercantum dalam surat edaran yang tidak menjadi bagian dari pembahasan tentang implementasi standar etika dalam birokrasi. Ada sejumlah konsep implementasi standar etika birokrasi yang belum dimuat dalam langkah-langkah untuk pemberantasan praktik pungli. Sebagai bahan masukan pemerintah dalam hal ini kementerian/lembaga/pemerintah daerah dapat menerapkan konsep yang belum dimuat dalam surat edaran 
untuk dilaksanakan sebagai langkah memberantas pungli, yaitu untuk:

- memperkuat kompetensi PNS dalam menerapkan kode etik, kode perilaku dan nilai-nilai integritas;

- membuat sejumlah kebijakan internal instansi untuk mencegah PNS melakukan pungli;

- membuat kode etik dan kode perilaku di lingkungan internal instansi dan menegakkan kepatuhan PNS untuk melaksanakannya;

- membuat langkah-langkah pencegahan praktek maladministrasi di lingkungan internal instansi;

- melaksanakan uji integritas terhadap PNS oleh lembaga independen;

- memberikan pemahaman kepada masyarakat yang dilayani untuk tidak mempengaruhi PNS yang bertugas melayani mereka untuk menerima pungli.

\section{KESMPULAN}

Dari pembahasan tentang upaya pemerintah memberantas praktik pungutan liat melalui upaya reformasi birokrasi area perubahan mental aparatur, sudah menunjukkan langkah-langkah yang mengadopsi implementasi standar etika birokrasi yang efektif. Namun, untuk lebih memperkuat langkah tersebut, setiap kementerian/lembaga/pemerintah daerah perlu melakukan sejumlah langkah tambahan berupa kebijakan di lingkungan internal masing-masing yang dapat memperkecil kemungkinan dan kesempatan bagi PNS untuk melakukan pungli.

\section{DAFTAR PUSTAKA}

Azhari, Siti Kusumawati. (2008). "Studi Pungli di Terminal, Stasiun Kereta Api, dan Pelabuhan Udara di Kota Bandung”. Jurnal Sosioteknologi Edisi 14 Tahun 7 Agustus 2008: 434-440. Diakses dari http://journals.itb.ac.id/index.php /sostek/article/view/1003/612. Tanggal akses 30 Oktober 2017. Harjanto. (2016). "Penerapan Sanksi Pidana Penjara dan Denda terhadap Pegawai Negeri Sipil yang melakukan Tindakan Pidana Korupsi Pungutan Liar: Studi di Pengadilan Tindak Pidana Korupsi Pontianak”. Jurnal Nestor Magister Hukum, 1(1). Diakses dari http:// jurnal.untan.ac.id/index.php/nest or/article/view/13496/12117.

Tanggal akses 30 Oktober 2017. Huerto Melchor, Oscar. (2008). "Managing Change in OECD Governments: An Introductory Framework". OECD Working Papers on Public Governance No. 12, OECD Publishing. 
Diakses

dari

http://www.oecd.org/gov/421422

31.pdf. Tanggal akses 4

November 2017.

Kementerian Dalam Negeri. (2016).

Presiden Jokowi Minta Hentikan

Pungli di Seluruh Instansi.

Sumber: Neraca.co.id. Diakses dari

http://www.kemendagri.go.id/ne ws/2016/10/12/presiden-jokowiminta-hentikan-pungli-diseluruh-instansi. Tanggal akses 1 November 2017

Kementerian PAN dan RB. (2016). Surat Edaran Menteri Pendayagunaan Aparatur Negara dan Reformasi Birokrasi Nomor 5 Tahun 2016 tentang Pemberantasan Praktik Pungutan Liar (Pungli) dalam Pelaksanaan Tugas dan Fungsi Instansi Pemerintah.

Komisi Pemberantasan Korupsi. (2015). Pedoman Pengendalian Gratifikasi. Diakses dari https://kpk.go.id/gratifikasi/BP/P edoman_Pengendalian_Gratifika si.pdf. Tanggal akses 1 November 2017

Ombudsman Republik Indonesia. (2017). Data Penyelesaian Laporan Masyarakat Triwulan III Tahun 2017 (Periode Juli September 2017). Diakses dari http://www.ombudsman.go.id/in dex.php/laporan/laporan- statistik.html\#. Tanggal akses 29 Oktober 2017

Peraturan Menteri Pendayagunaan Aparatur Negara dan Reformasi Birokrasi Nomor 11 Tahun 2015 tentang Road Map Reformasi Birokrasi 2015-2019. 2015. Jakarta: Kementerian Pendayagunaan Aparatur Negara dan Reformasi Birokrasi.

Pusat Kajian SANHAN. (2016). "Policy Brief: Mewujudkan Birokrasi Bebas Pungli sebagai Hakikat Agenda Reformasi Birokrasi”. Diakses dari http://lan.go.id/id/infoterbaru/policy-briefmewujudkan-birokrasi-bebaspungli-sebagai-hakikat-agendareformasi-birokrasi. Tanggal akses 30 Oktober 2017

Repucci, Sarah. (2014). "Designing Effective Civil Service Reform Lessons From Past Experience. Public Administration and Development, 34 (3: 207-218. Diakses dari http://onlinelibrary.wiley.com/do i/10.1002/pad.1684/pdf. Tanggal akses 4 November 2017.

Undang-Undang Nomor 5 Tahun 2014 tentang Aparatur Sipil Negara.

Whitton, Howard. (2001). Implementing Effective Ethics Standards in Government and the Civil Service. Diakses dari https://www.oecd.org/mena/gove 
Vol.4, No.1, April 2018

rnance/35521740.pdf. Tanggal akses 5 November 2017.

Wibawa, Samodra, Arya Fauzi F.M.

dan Ainun Habibah. (2013).

"Efektivitas Pengawasan

Pungutan Liar di Jembatan

Timbang”. Jurnal Ilmu

Administrasi Negara, 12 (2): 74-

85. Diakses dari

http://download.portalgaruda.org

/article.php? article $=129520 \& v a l$

=2287. Tanggal akses 30

Oktober 2017. 